\title{
LEACHATE PRODUCTION ANALYSIS AND ARRANGEMENT OF GAS VENT PIPELINES IN EX-LANDFILL SARBAGITA REGIONAL LANDFILL
}

\author{
Putu Ari Gayatri ${ }^{1}$ । Ellina Pandebesie ${ }^{* 2}$
}

\footnotetext{
${ }^{1}$ Department of Environmental Engineering, Institut Teknologi Sepuluh Nopember, Surabaya, Indonesia

${ }^{2}$ Department of Environmental Engineering, Institut Teknologi Sepuluh Nopember, Surabaya, Indonesia
}

\section{Correspondence}

*Ellina Pandebesie, Department of Environmental Engineering, Institut Teknologi Sepuluh Nopember, Surabaya, Indonesia. Email: ellina@its.ac.id

\section{Present Address}

Gedung Teknik Lingkungan, Kampus ITS Sukolilo, Jl. Raya ITS, Surabaya 60111, Indonesia

\begin{abstract}
Sarbagita Regional Landfill is a regional landfill which is located in Denpasar. At this time, there were closure and landfill arrangement in Sarbagita Regional Landfill. The utilization of ex-landfill land used as green open space requires leachate and gas handling due to the process of waste decomposition is still ongoing. Analysis of gas and leachate potential is needed for further management so that the surrounding environment is not polluted. Analysis of potential gas generation using a triangular method and analysis of leachate generation potential using the Thornwaite method. The maximum gas production occurs in 2023 at $43.367 .678,25 \mathrm{~m} 3 /$ year. Gas production gradually declined until it's estimated to run out in 2034. The number of gas pipe points needed is 19 points. Treatment methods that can be considered are the gas conversion to electricity method and the flaring method. The results of the calculation from leachate potential is 3.84 liters/second. The result will be used to planning a leachate processing installation. Processing system through 4 processing stages, namely processing in anaerobic ponds, facultative ponds, aerobic ponds, and biofilter ponds. Besides considering the technical aspects of technology selection, we also considered the Regional Government's capability and commitment as the manager.
\end{abstract}

\section{KEYWORDS:}

Gas, Leachate, Thornwaite, Triangular Method

\section{1 | INTRODUCTION}

Sarbagita Regional Landfill is a regional landfill located in Denpasar and covers an area of 32,4 Ha. Landfill serves the Sarbagita (Denpasar, Badung, Gianyar, Tabanan) region. In 2016, the Risk Index was assessed at Sarbagita Landfill with 627,5 ${ }^{11}$. A risk index attempts to guide the government and other implementing authorities for quick decision making for prioritizing actions 
related to dumpsite rehabilitation ${ }^{[2]}$. Based on the Minister of Public Works Regulation No. 03/2013, landfill with a risk index value of more than 600 must be closed.

Based on the information above, in December 2017, revitalization activities have started. One of the revitalization activities is the closure and redevelopment of the existing landfill into green open space. The community can utilize green free space, which is expected for recreation and sports. The redevelopment landfill into green open space covers an area of 22,4 Ha.

Leachate and gas potential analysis is needed because gas and leachate production is still ongoing. If it's not managed correctly, it has the potential to pollute the environment. Leachate potential analysis is used in the Thornwaite method. This method is based on assumptions that leachate only produces from rainfall entering landfill (percolation) (Damanhuri, 2012). This analysis is needed for leachate processing installation design. The installation will be used to process leachate so that it's safely disposed of water. The gas potential analysis is used in the triangular method. This method is depending on waste composition and waste moisture content ${ }^{3}$. The gas potential analysis is needed for gas management planning, including planning the number of gas pipes.

Living close to ex landfills is always assumed to have a declining and unhealthy quality of life. It is expected that the revitalization will gradually decrease the assumption. The development of ex-landfill as a public park could improve the quality of life and the comfort of the living environment as perceived by local communities ${ }^{[4}$. It is hoped that green open space at Sarbagita Regional Landfill will do the same for the community and benefit the environment. This paper aims to determine the gas production and leachate, which is caused by green open space in ex landfill and how to manage it.

\section{2 | MATERIAL AND METHOD}

\section{1 | Data Collection}

For this research, secondary data such as minimum rainfall and temperature data for ten years from the local meteorological station, covering open public space (RTH) development, waste management data in landfills. Primary data for this research, such as a specific weight of solid waste, waste composition, waste characteristic.

\section{2 | Leachate Production Analysis}

This study will conduct a leachate production analysis in open public space (RTH) Sarbagita Regional ex-Landfill. The quantity of leachate produced will depend a lot on the entry of water from the outside, mostly from rainwater, besides being influenced by the operational aspects applied, such as the application of overburden, surface slope, climatic conditions, etc. ${ }^{5}$. The analysis will use the Thornwaite method. There are twelve calculation step in thornwaite method

First step is calculating the monthly heat index. Given Equation 1, where IP represents the heat index and T represents the temperature.

$$
I P=\sum\left(\frac{T}{5}\right)^{1.514}
$$

Second step is calculating the potential for evaporation that has been calibrated (IP). The potential of evaporation (UPET) can be calculated as shown in Equation 2.

$$
U P E T=c \times\left(\frac{10 T}{\sum I P}\right)^{a}
$$

The $c$ is set to 1.62, $a$ is calculated using Equation 3 .

$$
a=0.000000675 I P^{3}-0.0000771 I P^{2}+0.01792 I P+0.49239
$$

The $T$ is the monthly temperature $\left({ }^{\circ} \mathrm{C}\right)$ and the $I P$ is the heat index. 
After UPET values are obtained, calibration needs to be done. Calibration is carried out with prolonged sun exposure factors based on the local meteorological station (correction factor $r$ ). Using Equation 4, we calculated PET.

$$
P E T=r \times U P E T
$$

The third step is calculating monthly precipitation data $(P)$. The monthly precipitation data is obtained from a local meteorological station.

The fourth step is calculating coefficient Run-off ( $C R o)$.Open green space used GCL (geosynthetic clay liner) at the top. Its type used is a combination of geomembrane, geotextile, and clay. And the rest use fertile soil type latosol, which is generally clay textured. The slope itself exceeds $7 \%$. Based on that, the run-off coefficient selected is 0,35 . After the run-off coefficient was obtained, we calculated Run-off using Equation 5.

$$
R o=P \times C R o
$$

The fifth step is calculating the infiltration $(I)$. The infiltration value is the number of rainwater that enters the covered soil. We calculated infiltration using Equation 6, $P$ is the precipitation.

$$
I=P-R o
$$

The six step is determining available water for storage $(I-P E T)$. An infiltration value minus the potential for evapotranspiration. Negative values indicate the amount of infiltration of water that fails to be supplied to the soil. In contrast, a positive value is an excess water during a specific period to fill the soil.

The seventh step is determining the accumulated Water Lost $(A P W L)$ value. A negative value from $(I-P E T)(S n e g(I-P E T))$, which is cumulative water loss. Sneg( $I-P E T)$ value is determined with the condition that if the $I-P E T$ value is $>0$, then Sneg $(I-P E T)$ will be 0 . But if the $I-P E T$ value is $<0$, then $S n e g(I-P E T)$ value is the accumulated values of $I-P E T$ that month and before

The eight step is determining the soil moisture storage $(S T)$. The soil moisture storage is the amount of water stored in the soil at equilibrium ${ }^{[6]}$. We calculated soil moisture storage using Equation 7.

$$
\text { ST = available_water } \times \text { cover_soil_thickness }
$$

If $\operatorname{Sneg}(I-P E T)=0$, then $S T$ value is based on a Equation 7. If $S n e g(I-P E T) \neq 0$, then used the Soil Moisture Retention Table $(S T=100 \mathrm{~mm}, S T=125 \mathrm{~mm}, S T=150 \mathrm{~mm})$

The ninth step is calculating $S T$ changes from the last month $(\Delta S T)$. The calculation is done by reducing $S T$ value in the month concerned with $S T$ value in the previous month according to Equation 8.

$$
\Delta S T=S T \text { value in the month concerned }-S T \text { value in the previous month }
$$

The tenth step is determining the actual evapotranspiration (AET) value. The amount of water lost significantly from month to month. The AET value represents the month's water evaporation value ${ }^{6}$. When soil moisture runs out, the evapotranspiration value is below its potential value. This calculation compares the value of I (infiltration) with PET. If $I>P E T$, then $A E T=A E T$. If $I<P E T$, then $A E T=I-\triangle S T$.

The eleventh step is determining the percolation $(P E R C)$ value. According to Damanhuri ${ }^{7}$, maximum percolation only occurs in the months where $I>P E T$. Whereas in the months where $I<P E T$, percolation did not happen. Percolation calculations are carried out in the following ways: If $I>P E T, P E R C=I-P E T-\triangle S T$ If $I<P E T, P E R C=0$ 
Determine leachate potential After obtaining percolation in 1 year, the maximum value is sought and then multiplied by the total area according to Equation 9.

$$
Q_{\text {lindi }}=P E R C(m m / b l n) \times \text { total_area }
$$

\section{3 | Gas Production}

This study will conduct gas production analysis in green open space Sarbagita Regional ex-landfill. The analysis used the triangular method. The following are the calculation steps for Triangular method.

First step is determining the dry weight of the wet weight of the waste and the elemental composition of each type of waste. The second step is dividing previously obtained waste composition data that has been into two groups. The grous are rapidly and slowly decomposable organic constituents. In this step is also determining the percentage distribution of the major elements composing the waste.

The fourth step is determining the chemical formula of waste in the form of $\mathrm{C}, \mathrm{H}, \mathrm{O}, \mathrm{N}$ with $\mathrm{N}$ considered 1. Estimate the amount of gas that can be derived from the rapidly and slowly decomposable organic constituents in solid waste used formula (10), formula (11) and (12) to determine the volume of $\mathrm{CH} 4$ and $\mathrm{CO} 2$ production, and formula (13) and (14) to determine the total theoretical amount of gas generated per unit dry weight of organic matter destroyed.

$$
\begin{aligned}
& \mathrm{C}_{a} \mathrm{H}_{b} \mathrm{O}_{c} \mathrm{~N}_{d}+\left(\frac{4 a-b-2 c+3 d}{4}\right) \mathrm{H}_{2} \mathrm{O} \rightarrow\left(\frac{4 a+b-2 c-3 d}{8}\right) \mathrm{CH}_{4}+\left(\frac{4 a-b+2 c+3 d}{8}\right) \mathrm{CO}_{2}+d \mathrm{NH}_{3} \\
& \mathrm{CH} 4=\frac{\left(\text { mole_weightCH} H_{4} \times d r y \_ \text {weight_slowly } / \text { rapidly }\right)}{\text { mole_weight } C_{a} H_{b} O_{c} N_{d} \times \text { specificweightCH} H_{4}} \\
& \mathrm{CO} 2=\frac{\left(\text { mole_weightCO} \mathrm{O}_{2} \times d r y \_w e i g h t \_s l o w l y / r a p i d l y\right)}{{\text { mole_weight } C_{a} \mathrm{H}_{b} \mathrm{O}_{c} N_{d} \times \text { specific_weightCO}}_{2}} \\
& \text { Rapidly_decomposable }=\frac{V o l . C H_{4}+V o l . C O_{2}}{d r y \_w e i g h t \_r a p i d l y \_d e c o m p o s a b l e} \\
& \text { Slowly_decomposable }=\frac{\left.V o l . C H_{4}+V o l . C O_{2}\right)}{d r y \_w e i g h t \_s l o w l y \_d e c o m p o s a b l e}
\end{aligned}
$$

The last step is determining the amount of gas that has been produced at the end of each year of rapidly and slowly biodegradable organic waste material ${ }^{[8]}$. Five years period for rapidly and 15 years for slowly.

\section{3 | RESULTS AND DISCUSSION}

\section{1 | Gas Production Analysis}

Table 1. presented the weight of solid waste that enters landfills from 2014 to 2018 . The composition of the waste is obtained from the waste composition survey results for eight consecutive days at Sarbagita Regional Landfill. The moisture content data is based on Abdoli et al. ${ }^{[9]}$ The result of calculating the dry weight is presented in Table 2.

The distribution of waste decomposition is presented in Table 3. Table 4 presents the estimated chemical in Equation 10. Based on Table 4 and Equation 10, the chemical procedures without sulfur can be obtained as follow.

$$
\begin{aligned}
& \text { Rapidly_decomposed }=\mathrm{C}_{31} \mathrm{H}_{49} \mathrm{O}_{2} \mathrm{ON}+9 \mathrm{H}_{2} \mathrm{O} \rightarrow 16 \mathrm{CH}_{4}+15 \mathrm{CO}_{2}+\mathrm{NH}_{3} \\
& \text { Slowly_decomposed }=\mathrm{C}_{62} \mathrm{H}_{89} \mathrm{O}_{24} \mathrm{~N}+28 \mathrm{H}_{2} \mathrm{O} \rightarrow 37 \mathrm{CH}_{4}+26 \mathrm{CO}_{2}+\mathrm{NH}_{3}
\end{aligned}
$$


TABLE 1 Weight of solid waste entering landfill.

\begin{tabular}{cc}
\hline Year & $\begin{array}{c}\text { Weight of Solid } \\
\text { Waste (m3/day) }\end{array}$ \\
\hline 2014 & $2.810,03$ \\
2015 & $3.557,00$ \\
2016 & $4.312,00$ \\
2017 & $4.789,00$ \\
2018 & $6.300,95$ \\
\hline
\end{tabular}

TABLE 2 Calculation of dry weight from each waste component.

\begin{tabular}{lccc}
\hline Component & $\begin{array}{c}\text { Wet Weight } \\
(\mathbf{m} 3 / \text { day })\end{array}$ & $\begin{array}{c}\text { Moisture } \\
\text { Content }(\%)\end{array}$ & $\begin{array}{c}\text { Dry Weight } \\
\text { (kg) }\end{array}$ \\
\hline Food Wastes & 29,98 & 70 & 8,99 \\
Yard Wastes & 22,74 & 60 & 9,10 \\
Wood & 6,35 & 20 & 5,08 \\
Plastic & 15,84 & 2 & 15,53 \\
Paper & 10,66 & 6 & 10,02 \\
Rubber & 0,33 & 2 & 0,32 \\
Leather & 0,06 & 10 & 0,06 \\
Textiles & 3,58 & 10 & 3,22 \\
Cardboard & 1,44 & 5 & 1,37 \\
TOTAL & 90,98 & & 53,68 \\
\hline
\end{tabular}

TABLE 3 Distribution of waste components based on decomposition rate.

\begin{tabular}{lccc}
\hline Component & $\begin{array}{c}\text { Rapidly } \\
\text { Decomposed } \\
(\mathbf{K g})\end{array}$ & Component & $\begin{array}{c}\text { Slowly } \\
\text { Decomposed } \\
(\mathbf{K g})\end{array}$ \\
\hline Food Wastes & 8,99 & Wood & 5,08 \\
Yard Wastes & 5,46 & Plastic & 15,53 \\
Paper & 10,02 & Rubber & 0,32 \\
Cardboard & 1,37 & Leather & 0,06 \\
& & Textiles & 3,22 \\
TOTAL & 25,84 & Yard Wastes & 3,64 \\
\hline
\end{tabular}

TABLE 4 The estimation of chemical without sulfur.

\begin{tabular}{lccc}
\hline \multirow{2}{*}{ Notation } & \multirow{2}{*}{ Component } & \multicolumn{2}{c}{ Mole Ratio } \\
& & Rapidly & Slowly \\
\hline a & C & 31 & 62 \\
b & H & 49 & 89 \\
c & O & 20 & 24 \\
d & N & 1 & 1 \\
\hline
\end{tabular}

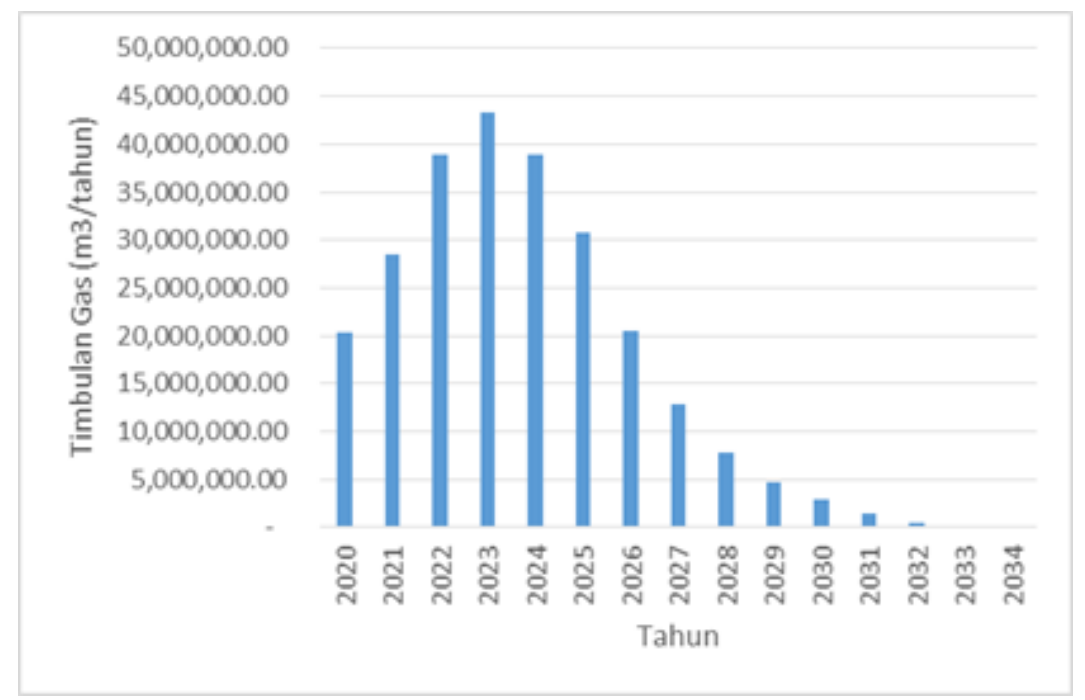

FIGURE 1 The framework of proposed method.

Based on the chemical formula above, estimated volume $\mathrm{CH}_{4}$ and $\mathrm{CO}_{2}$ produce can be known using Equation 11 and 12, as presented in Table 5. The total theoretical amount of gas generated per unit dry weight of organic matter destroyed can be known using Table 4 and Equation 13 and 14.

Rapidly_decomposed $=0,915 \mathrm{~m} 3 / \mathrm{kg}$

Slowly_decomposed $=1,136 \mathrm{~m} 3 / \mathrm{kg}$ 


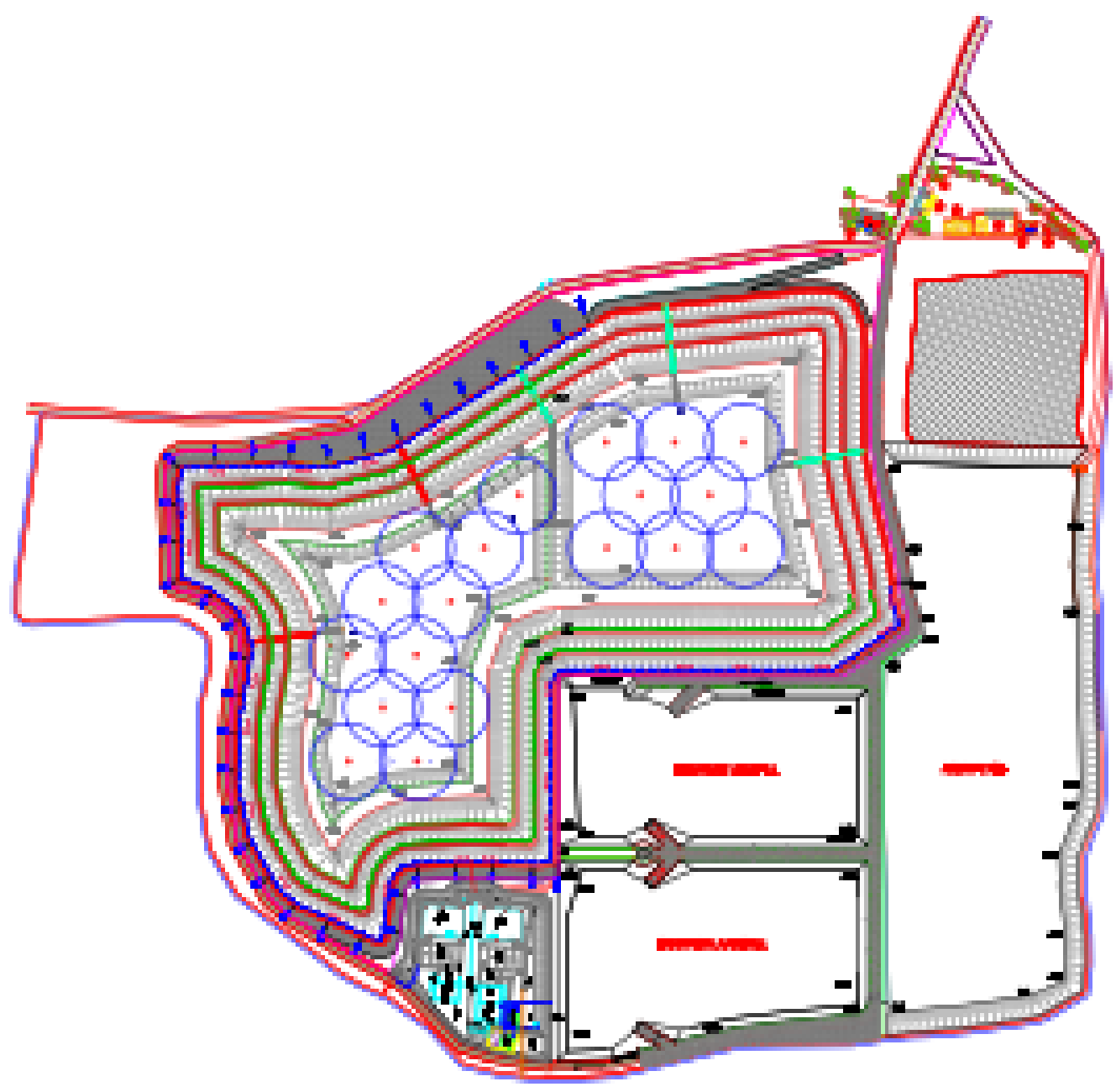

FIGURE 2 Gas pipe point at open green space Sarbagita Regional ex-landfill.

To determine the gas generation in landfills, it can be calculated by multiplying the theoretical amount of gas generated and gas production per year. The weight of solid waste entering landfills in Table 1 must be calculated for 15 years for each year's data. The estimated amount of gas per year is obtained, and it will gradually run out by 2034, as shown in Figure 1.

Revitalization of Sarbagita Regional Landfill completed in 2019 so that gas can be utilized in 2020. Gas potential from 2020 in Sarbagita Regional Landfill as present in Figure 1. Based on Figure 1, maximum gas production occurs in 2023 in the amount of 43.367.678,25 m3/year. Gas production will gradually run out by 2034 .

\section{2 | Gas Pipe Arrangement}

To drain and reduce the accumulation of gas pressure, a ventilation pipe is needed. The gas capturing system which can be used is vertical gas ventilation. Vertical gas ventilation is ventilation that directs and flows gas formed upwards. There are serveral vertical piping design criteria which are based on Minister of Public Works Regulation No. 03/2013. The criteria are (1) pipe gas with casing PVC/PE/HDPE: $150 \mathrm{~mm}$ minimum, (2) drill hole filled with gravel: $50-100 \mathrm{~cm}$; (3) pipe perforated: $8-12 \mathrm{~mm}$, (4) depth of drill hole: $80 \%$, and (5) distance between vertical vents: $25-50 \mathrm{~m}$.

Based on the criteria above, using the distance between vertical vents about $45 \mathrm{~m}$, the numbers of gas pipe at zone $2 \mathrm{~b}$ were 11 points, and zone 2 a was 8 points. So the total number of gas pipe points was 19 points, as shown in Figure 2 . 
There are several gas management methods, including the flaring method and the technology of converting methane gas into electricity [10,13]. Based on Zhu et al. ${ }^{[14]}$, the technology for converting methane gas into electricity is the Internal Combustion Engine.

Technology for converting methane gas into electricity has benefits for the surrounding community and landfill managers. The technology is easy to apply and has been used to maximize the gas potential to become electricity. Overall research in the USA found that 1 million tons of waste could be converted to 0,8 megawatts of electricity ${ }^{[15]}$. By estimating the solid waste that goes into landfill as much as $6.300,95 \mathrm{~m} 3 /$ day or equal to $653.154,18$ ton/year, the potential to convert solid waste into electricity as much as 0,52 Megawatt of electricity. The conversion of methane gas into electricity can change $100 \%$ of the methane gas taken. This method's working principle is to trigger gas from the landfill with air in the combustion chamber. This technology is easy to build and can work up to 20 years of use when properly cared for. The disadvantage of this technology is that the conversion process has pollution potential, namely noise and CO. Noise level produced by this technology is typically $80-110$ $\mathrm{dB}$. So noise reduction will mostly be needed.

The primary purpose of landfill gas flare is to safely dispose of the flammable constituents of landfill gas and control odor nuisance, health risk, and adverse environmental impacts. Good combustion depends on the ability to maintain high temperatures for a particular time. There are two types of flaring that can be chosen: open and enclosed ground flaring.

Open flares burn gas landfills in open spaces. There is often a shield around the burner to protect the flame from the wind. The advantages of open flare are inexpensive and relatively simple. The disadvantages of the open flare method are inefficient. Thus, it is resulting in a very low emissions than enclosed ground flare. There are three reasons which can explain why open flare cannot be expected to produce low emissions and good combustion. First, an open flare with its unconfined flame is usually unable to reach the high temperature. Second, luminous flames radiate heat, and there is no way to reduce heat loss. Lastly, ambient air cools the edges of the combustion and tends to extinguish the reaction.

Enclosed Ground Flaring burn landfill gas in a vertical cylindrical or rectilinear enclosure. This method allows operation at a higher temperature. Other than that, this method is often insulated to reduced heat losses. The concept of landfill gas flare technology is straightforward. Landfill gas is brought into contact with a supply of air and ignited. The method only has to maintain the air supply so that it is capable of completing combustion. So it meets the applicable emissions standards. The disadvantages of this method are noise, and if the process does not run correctly, it can give rise to dioxins, furans, hydrocarbons, and NOX, so it must be monitored within $1 \mathrm{~km}$. The costs required for these installations is $1.5-2$ times from open flare installations. Other than that, this method has a destruction rate of about $90 \%$. There are seven necessary components needed for this method. First, gas cleaning to remove moisture and possibly impurities from the landfill gas before the flare. Second, a blower, developing the head of pressure needed to feed landfill gas to the flare. Third, a fire retardant to prevent flash-back of the flame down the pipe. Fourth, the methods to control the flow rate of landfill gas to the burner. Fifth, an ignition system to light the gas mixture on start-up. Sixth, a fire detector to check whether the ignition has been successful and burning is occurring. Finally, the burner, which is designed to retain turbulence mixing air and fuel and speed gas

The selection from these two methods depends on the local government's ability as the manager, besides the technical aspect. When a technology has been chosen, the manager must have prepared supporting things both in terms of human resources and costs so that the gas management process can run properly.

\section{3 | Leachate Production Analysis}

The result obtained from this calculation is percolation in 12 months, as shown in Table 6. Choose the most significant result and multiply it with the total green open space area, as mentioned in formula (9). The maximum percolation that occurs in 12 months is $78,46 \mathrm{~mm} / \mathrm{month}$. The total area of open green space is $126.900 \mathrm{~m} 2$. So the leachate production obtained is 3,84 liter/second.

This result would be used for leachate processing installation design. Leachate processing installation functions are to treat leachate produced by open green space. So the development of its process will safely be disposed into water.

The selection of processing systems on leachate processing installation based on considerations that are easy to operate, decreasing waste concentration, and the system applied is easy to understand. It must be remembered that the management of green open space will be carried out by the regional government, where human resources usually limit there. 
Based on studies that have been conducted by Satker PSPLP Provinsi Bali in 2016, recommended processing through 4 phases, namely: processing through anaerobic ponds, facultative ponds, aerobic ponds, biofilter ponds.

The processing of anaerobic systems is used to treat high content organic matter. Large organic particles settle at the bottom of the pond and then broken down by microorganisms through anaerobic processes. The $\mathrm{pH}$ of the pond must be kept above six by adding quicklime. The mud collected at the bottom of the pond must be cleaned at least twice a year.

Facultative ponds can be operated for lower organic loads because they have been processed in anaerobic ponds first. Processing in facultative ponds decreases organic matter, which occurs a symbiotic reaction between algae and bacteria. In the upper part, which is placed by algae, photosynthesis will appear and produce high oxygen. Oxygen will be used by bacteria to degrade organic matter in leachate. In the middle layer, that acts as facultative bacteria. The amount of oxygen thinning due to the lack of algae and sunlight that enters this layer. The condition that occurs is between aerobics, so it is called a facultative condition. At the bottom of the pool, an anaerobic process occurs where dead microorganisms settle to the bottom of the pond and decompose organic matter by anaerobic bacteria. This process produces $\mathrm{CO} 2, \mathrm{CH} 4, \mathrm{NH} 3$, and $\mathrm{H} 2 \mathrm{~S}$ gases.

Aerobic ponds function as aeration ponds. Because it uses a blower/aerator. The efficiency of decreasing organic matter is relatively high, but because the outflow also carries suspended solids, decreasing suspended solids in effluents is too low. Aerobic ponds walls are made from reinforced concrete. The pond floor uses a liner layer to prevent leakage. To set aside the remaining heavy metals from the previous treatment, additional processing is proposed with a biofilter pond.

Biofilter ponds can utilize soil properties in adsorbing substances, including ion exchange properties, combined with individual plants' heavy metals. The biofilter pond's effluent is recommended to be accommodated first in the storage pond then flowed into the water.

The selection from these two methods depends on the local government's ability as the manager, besides the technical aspect. When a technology has been chosen, the manager must have prepared supporting things both in terms of human resources and costs so that the gas management process can run properly.

\section{4 | Leachate Production Analysis}

The result obtained from this calculation is percolation in 12 months, as shown in Table 6 . Choose the most significant result and multiply it with the total green open space area, as mentioned in formula (9). The maximum percolation that occurs in 12 months is $78,46 \mathrm{~mm} / \mathrm{month}$. The total area of open green space is $126.900 \mathrm{~m} 2$. So the leachate production obtained is 3,84 liter/second.

This result will be used for leachate processing installation design. Leachate processing installation functions are to treat leachate produced by open green space. So the development of its process will safely be disposed into water.

The selection of processing systems on leachate processing installation based on considerations that are easy to operate, decreasing waste concentration, and the system applied is easy to understand. It must be remembered that the management of green open space will be carried out by the regional government, where human resources usually limit there.

Based on studies that have been conducted by Satker PSPLP Provinsi Bali in 2016, recommended processing through 4 phases, namely: processing through anaerobic ponds, facultative ponds, aerobic ponds, biofilter ponds.

The processing of anaerobic systems is used to treat high content organic matter. Large organic particles settle at the bottom of the pond and then broken down by microorganisms through anaerobic processes. The $\mathrm{pH}$ of the pond must be kept above six by adding quicklime. The mud collected at the bottom of the pond must be cleaned at least twice a year.

Facultative ponds can be operated for lower organic loads because they have been processed in anaerobic ponds first. Processing in facultative ponds decreases organic matter, which occurs a symbiotic reaction between algae and bacteria. In the upper part, which is placed by algae, photosynthesis will appear and produce high oxygen. Oxygen will be used by bacteria to degrade organic matter in leachate. In the middle layer, that acts as facultative bacteria. The amount of oxygen thinning due to the lack of algae and sunlight that enters this layer. The condition that occurs is between aerobics, so it is called a facultative condition. At the bottom of the pool, an anaerobic process occurs where dead microorganisms settle to the bottom of the pond and decompose organic matter by anaerobic bacteria. This process produces $\mathrm{CO} 2, \mathrm{CH} 4, \mathrm{NH} 3$, and $\mathrm{H} 2 \mathrm{~S}$ gases. 
Aerobic ponds function as aeration ponds. Because it uses a blower/aerator. The efficiency of decreasing organic matter is relatively high, but because the outflow also carries suspended solids, decreasing suspended solids in effluents is too low. Aerobic ponds walls are made from reinforced concrete. The pond floor uses a liner layer to prevent leakage. To set aside the remaining heavy metals from the previous treatment, additional processing is proposed with a biofilter pond.

Biofilter ponds can utilize soil properties in adsorbing substances, including ion exchange properties, combined with individual plants' heavy metals. The biofilter pond's effluent is recommended to be accommodated first in the storage pond then flowed into the water.

\section{4 | CONCLUSION}

Gas potential in open green space ex-landfill can be utilized in 2020. The maximum gas potential occurs in 2023 as much as 43.367.678,25 m3/year. And gradually will decrease until it's run out in 2034. To drain and reduce the accumulation of gas pressure, a vertical ventilation pipe is needed. Its need 19 pipe gas point is divided into two zones, namely zone $2 \mathrm{~b}, 11$ points, and zone $2 \mathrm{a}$ is 8 points. There are several gas management methods, including the flaring method and the technology of converting methane gas into electricity. Each method has its advantages and disadvantages. Leachate potential is known to equal 3,84 liter/second. This result will be used for leachate processing installation design. Leachate processing installation functions are to treat leachate, so its process will safely be disposed into water. The selection of processing systems on leachate processing installation based on considerations that are easy to operate, the efficiency of decreasing waste concentration, and design applied are easy to understand. The recommended treatment system for green open space in Sarbagita Regional landfill is through 4 processes in the sequence: anaerobic ponds, facultative ponds, aerobic ponds, and biofilter ponds. Regional governments' ability as managers also influence the selection of processing technology for gas and leachate. The capabilities are related to human resources and the availability of costs to carry out operations and maintenance of selected technologies. So the treatment process of gas and leachate will run properly.

\section{References}

1. Satker Pengembangan Penyehatan Lingkungan Permukiman Provinsi Bali. Evaluasi Sistem Pengelolaan Sampah TPA Sarbagita, Satker PSPLP Provinsi Bali, Denpasar. Bali: Satker Pengembangan Penyehatan Lingkungan Permukiman Provinsi Bali; 2016.

2. Ailton JGM, Juliano CG, Joana dBM, Armando BDCJ. Application of a decision support tool for municipal solid waste open dumps remediation in Cape Verde. African Journal of Environmental Science and Technology 2020;14(2).

3. Setiyowati P, Trihadiningrum DY. Pengelolaan Emisi Gas pada Penutupan TPA Gunung Tugel di Kabupaten Banyumas. In: Prosiding Seminar Nasional Manajemen Teknologi XIX Surabaya: MMT ITS; 2013. p. 1-8. http://mmt.its.ac.id/download/ SEMNAS/SEMNASXIX/MTL/1.PujiSetiyowati.pdf

4. Simis M, Awang A, Arifin K. From Ex-landfill to Public Park: Impact on Local Community's Quality of Life and Living Environment. Procedia - Social and Behavioral Sciences 2016 jun;222:763-771.

5. Nonistantia, Prayogo TB, Yuliani E. Analisa Prediksi Produksi Debit Lindi Tahun 2014-2015 Dengan Metode Neraca Air Thornwaite di Tpa Supit Urang Kota Malang. PhD thesis, Universitas Brawijaya; 2016.

6. Tian Y, Xiong L, Xiong B, Zhuang R. A Prior estimation of the spatial distribution parameter of soil moisture storage capacity using satellite-based root-zone soil moisture data. Remote Sensing 2019;11(21).

7. Made I, Widyarsana W, Damanhuri E, Agustina E, Aulia RN. Risk Assessment and Rehabilitation Potential of Municipal Solid Waste Landfills iin Bali Province, Indonesia. International Journal of GEOMATE 2019;17(63):164-171. https: //doi.org/10.21660/2019.63.39057.

8. Adipraja PFE, Islamiyah M, Wahyuni I. Utilization Management of Landfill Zones Based on Volume of Municipal Organic Waste Simulation. IPTEK The Journal for Technology and Science 2018 jul;29(1):853-4098. http://iptek.its.ac.id/index. 
php/jts/article/view/3015

9. Abdoli MA, Rezaei M, Hasanian H. Integrated solid waste management in megacities. Global Journal of Environmental Science and Management 2016;2(3).

10. Lee U, Han J, Wang M. Evaluation of landfill gas emissions from municipal solid waste landfills for the life-cycle analysis of waste-to-energy pathways. Journal of Cleaner Production 2017;166(1):335-342.

11. Ayodele TR, Ogunjuyigbe ASO, Alao MA. Economic and environmental assessment of electricity generation using biogas from organic fraction of municipal solid waste for the city of Ibadan, Nigeria. Journal of Cleaner Production 2018;203(1):718-735.

12. Alzate S, Restrepo-Cuestas B, Jaramillo-Duque Á. Municipal solid waste as a source of electric power generation in Colombia: A techno-economic evaluation under different scenarios. Resources 2019;8(1):1-16.

13. Ng KS, Yang A, Yakovleva N. Sustainable waste management through synergistic utilisation of commercial and domestic organic waste for efficient resource recovery and valorisation in the UK. Journal of Cleaner Production 2019;227(1):248262. https://www.sciencedirect.com/science/article/pii/S0959652619312156?via\{\%\}3Dihub.

14. Zhu S, Hu B, Akehurst S, Copeland C, Lewis A, Yuan H, et al. A review of water injection applied on the internal combustion engine. Energy Conversion and Management 2019;184(1):139-158. https://www.sciencedirect.com/science/article/pii/ S0196890419300883?via\{\%\}3Dihub

15. García PEE. Efficiency and reliability of theoretical models of biogas for landfills. Granja 2019;29(1):1-17. https://www. redalyc.org/jatsRepo/4760/476058342003/476058342003.pdf

How to cite this article: Gayatri P.A., Pandebesie E., (2020), Leachate Production Analysis and Arrangement of Gas Vent Pipelines in Ex-Landfill Sarbagita Regional Landfill, IPTEK The Journal of Technology and Science, 31(2):201-210. 